\title{
PENGUATAN PERAN PERPUSTAKAAN DESA DALAM DISEMINASI INFORMASI KESEHATAN LINGKUNGAN
}

\author{
Saleha Rodiah, Agung Budiono, dan Neneng Komariah \\ Program Studi Ilmu Perpustakaan (FIKOM / Universitas Padjadjaran) \\ E-mail: saleha.rodiah@unpad.ac.id
}

\begin{abstract}
ABSTRAK. Informasi kesehatan merupakan hal yang sangat penting untuk diketahui oleh masyarakat agar masyarakat memiliki kesadaran dan berpartisipasi aktif dalam penerapan pola hidup bersih dan sehat. Oleh karena itu diseminasi informasi kesehatan sangat penting untuk dilakukan bukan hanya oleh Dinas Kesehatan, tetapi juga oleh institusi sosial baik formal maupun nonformal. Perpustakaan desa merupakan salah satu unit kerja di bawah pemerintah desa yang berfungsi sebagai sarana belajar masyarakat melalui sumber-sumber informasi yang tersedia. Oleh karena itu sangat tepat apabila perpustakaan desa berperan aktif dalam diseminasi informasi kesehatan. Kegiatan PKM ini bertujuan memberikan wawasan pengetahuan mengenai upaya penguatan perpustakan desa dalam aspek fasilitas, koleksi sumber-sumber informasi, staf perpustakaan, dan kebijakan yang mendukung dari pemerintah desa berkaitan dengan dana, staf perpustakaan, dan sosialisasi perpustakaan pada masyarakat. Perpustakaan desa yang sudah optimal dapat berperan dalam diseminasi informasi kesehatan melalui penyediaan koleksi tentang kesehatan, dan staf perpustakaan berperan sebagai fasilitator informasi kesehatan.
\end{abstract}

Kata kunci: informasi kesehatan; perpustakaan desa; kecamatan ngamprah; kabupaten bandung barat

\begin{abstract}
Health information is a very important thing for the community to know so they will have an awareness and actively participates in the implementation of a clean and healthy lifestyle. Therefore the dissemination of health information is very important to be done not only by the Health Office, but also by social institutions both formal and non-formal. The village library is a unit of the village government which functions as a community learning center by providing collections of information sources. Therefore, it is very appropriate if village libraries play an active role in the dissemination of health information. The PKM activity aims to provide insights on the efforts to strengthen village libraries in aspects of facilities, collections of information sources, library staff, and supporting policies from the village government regarding funds, library staff and library promotion. Village libraries that have been developed optimally can play a role in the dissemination of health information through the provision of collections about health information, and library staff could be as facilitators in providing health information.
\end{abstract}

Key words: health information; village library; Ngamprah sub-district; West Bandung regency

\section{PENDAHULUAN}

Upaya menjadi anggota masyarakat yang literat informasi kesehatan menjadi hak setiap warga negara. Sebagaimana tertuang dalam Undang-undang Republik Indonesia disebutkan bahwa: Setiap orang berhak untuk mendapat informasi dan edukasi tentang kesehatan yang seimbang dan bertanggung jawab (Undang-Undang Republik Indonesia Nomor 36 Tahun 2009 Tentang Kesehatan, 2009). Dalam Peraturan Pemerintah Republik Indonesia disebutkan bahwa: Informasi Kesehatan adalah Data Kesehatan yang telah diolah atau diproses menjadi bentuk yang mengandung nilai dan makna yang berguna untuk meningkatkan pengetahuan dalam mendukung pembangunan kesehatan (Undang-Undang Nomor 46 Tahun 2014 tentang Sistem Informasi Kesehatan, 2014).

Informasi dan edukasi tentang kesehatan dapat diperoleh dari berbagai sumber dokumen, manusia, lembaga, benda maupun situasi. Melalui dokumen seorang ibu dapat mengetahui jadwal imunisasi balitanya, melalui benda (alat timbangan) seorang ibu mendapatkan informasi mengenai kenaikan berat badannya di posyandu serta melalui petugas kesehatan, ibu tersebut mengetahui informasi status gizi dan kesehatan anaknya.

Kegiatan diseminasi (penyebaran) informasi kesehatan merupakan aspek penting yang dapat mempercepat keberhasilan pencapaian tujuan pembangunan kesehatan. Disamping itu proses penyebaran informasi yang berhasil akan mampu memberikan multiplying effect yang signifikan. Diantara berbagai informasi kesehatan, maka informasi kesehatan tentang pemberdayaan masyarakat, yaitu informasi mengenai: a) jenis organisasi kemasyarakatan yang peduli kesehatan; dan b) hasil kegiatan pemberdayaan masyarakat bidang kesehatan, termasuk penggerakan masyarakat adalah sangat penting untuk didesiminasikan. Selain itu Rodiah, Lusiana, \& Agustine (2016) menyebutkan bahwa pemberdayaan masyarakat (perempuan) dalam bidang diseminasi (penyebarluasan) informasi kesehatan amat penting sehingga diharapkan dapat menyebarluaskan informasi kesehatan pada keluarga, kelompok, dan masyarakat di lingkungannya secara terarah dan berkesinambungan.

Kami Tim Pengabdian pada Masyarakat (PPM) Progran Studi Ilmu Perpustakaan tertarik berpartisipasi aktif dalam Penguatan Peran Perpustakaan Desa dalam Mendukung Diseminasi Informasi Kesehatan.

Diseminasi informasi kesehatan bidang bukan hanya tanggungjawab dinas kesehatan dan jajarannya, namun juga merupakan tanggungjawab setiap anggota masyarakat dan organisasi formal maupun informal di suatu lingkungan masyarakat. Apabila banyak pihak yang ambil bagian dalam kegiatan diseminasi informasi kesehatan, diharapkan masyarakat akan lebih peduli dan berperan serta aktif dalam menciptakan lingkungan yang sesuai dengan Pola Hidup Bersih Sehat (PHBS). 
Salah satu institusi sosial yang hadir di tengah masyarakat dan berfungsi sebagai sarana pendidikan nonformal adalah perpustakaan umum. Undang-Undang No. 43 Tahun 2007 Tentang Perpustakaan, mendefinisikan perpustakaan umum adalah perpustakaan yang diperuntukkan bagi masyarakat luas sebagai sarana pembelajaran sepanjang hayat tanpa membedakan umur, jenis kelamin, suku, ras, agama, dan status sosial-ekonomi (Undang-Undang Republik Indonesia Nomor 43 Tahun 2007 tentang Perpustakaan, 2007). Jadi di perpustakaan umum semua anggota masyarakat dapat memperoleh sumber-sumber informasi sebagai sumber belajar mandiri sepanjang hayat (lifelong learning), sehingga perpustakaan umum sering disebut sebagai universitas untuk masyarakat (NS, 2006).

Selanjutnya Undang-Undang tentang Perpustakaan menjelaskan bahwa perpustakaan umum diselenggarakan oleh Pemerintah, pemerintah provinsi, pemerintah kabupaten/ kota, kecamatan, dan desa, serta dapat diselenggarakan oleh masyarakat.

Perpustakaan desa merupakan salah satu jenis perpustakaan umum yang berkedudukan di suatu desa/kelurahan, sehingga lebih mudah dijangkau oleh masyarakat yang berada di suatu wilayah pedesaan. Menurut SK Menteri Dalam Negeri dan Otonomi Daerah, "Perpustakaan desa/kelurahan merupakan perpustakaan umum/masyarakat sebagai salah satu sarana/media untuk meningkatkan dan mendukung kegiatan pendidikan masyarakat pedesaan yang merupakan bagian integral dari kegiatan pembangunan desa/kelurahan." (Keputusan Menteri Dalam Negeri Dan Otonomi Daerah Nomor 3 Tahun 2001 tentang Perpustakaan Desa/Kelurahan, 2001). Jadi perpustakaan desa merupakan sarana belajar masyarakat dimana idealnya tersedia berbagai sumber informasi dalam berbagai format sebagai sumber belajar masyarakat. Oleh karena itu, sumber-sumber informasi yang merupakan koleksi perpustakaan desa harus meliputi berbagai subjek pengetahuan termasuk di dalamnya tentang kesehatan. Jadi perpustakaan desa dapat berperan aktif dalam diseminasi informasi kesehatan.

Berdasarkan kondisi tersebut, maka masalah yang akan dibahas adalah bagaimana upaya penguatan peran perpustakaan desa dalam diseminasi informasi kesehatan. Adapun masalah penelitian secara spesifik adalah sebagai berikut:

1. Bagaimana upaya memperkuat peran perpustakaan desa sebagai sumber informasi kesehatan

2. Bagaimana pengelola perpustakaan desa dapat berperan aktif sebagai fasilitator diseminasi informasi kesehatan.

Selanjutnya manfaat kegiatan PPM ini adalah sebagai berikut:

1. Pengelola perpustakaan desa dapat mempromosikan keberadaan dan layanan perpustakaan pada masyarakat 2. Pengelola perpustakaan desa dapat memilih dan melakukan pengadaan koleksi yang efisien dan efektif sesuai dengan kebutuhan penggunanya

3. Masyarakat memahami fungsi perpustakaan dan dapat memanfaatkan koleksi perpustakaan sebagai sumber informasi, khususnya informasi kesehatan.

\section{METODE}

Sasaran kegiatan pengabdian masyarakat ini adalah para pengelola perpustakaan desa di wilayah kerja Puskesmas Cimareme, Kecamatan Ngamprah, Kabupaten Bandung Barat. Di wilayah ini terdapat Desa Margajaya, Cimareme, Cilame, Tani Mulya, Pakuhaji, dan Suka Tani. Adapun lokasi pelaksanaan kegiatan PPM bertempat di Aula Kantor Desa Margajaya.

Metode pelaksanaan kegiatan PPM ini terdiri dari beberapa tahap sebagai berikut: 1) tahap persiapan yang terdiri dari koordinasi internal tim PKM, survey lokasi kegiatan, mengurus perijinan ke instansi terkait, pembuatan instrumen PKM dan materi untuk kegiatan bermain peran. 2) Pelaksanaan diskusi para peserta pelatihan dengan metode bermain peran, yaitu peserta pelatihan berdiskusi menggali beberapa permasalahan yang ada dalam pengembangan perpustakaan desa untuk selanjutnya mereka mencari jalan keluar untuk mengatasi masalah tersebut dengan bermain peran, seperti menjadi staf perpustakaan, pengguna perpustakaan, kepala desa. 3) tahap monitoring dan evaluasi sebagai umpan balik pelaksanaan PPM.

\section{HASIL DAN PEMBAHASAN}

Perpustakaan desa yang menjadi sasaran kegiatan terdiri dari perpustakaan desa Margajaya, Cimareme, Cilame, Tani Mulya, Pakuhaji, dan Gadobangkong. Desa-desa tersebut merupakan wilayah kerja Puskesmas Cimareme, Kecamatan Ngamprah, Kabupaten Bandung Barat. Kondisi perpustakaan desa di wilayah tersebut dalam keadaan relatif cukup baik. Sudah memiliki ruangan tersendiri, memiliki sejumlah koleksi yang disimpan di rak dengan subjek dan judul yang bervariasi, memiliki staf yang bertugas mengelola perpustakaan tersebut. Di salah satu perpustakaan desa, yaitu di perpustakaan Desa Margajaya sudah memiliki tiga unit komputer yang bisa digunakan untuk mengakses internet dan pelatihan komputer bagi masyarakat yang membutuhkan. Namun perpustakaan-perpustakaan desa tersebut masih memiliki beberapa kelemahan. Antara lain kelemahan pertama adalah dari aspek staf yang mengelola perpustakaan. Mereka pada umumnya adalah ibu-ibu kader PKK atau di desa Suka Tani dikelola oleh pengurus Karang Taruna yang tidak memiliki pengetahuan yang memadai tentang bagaimana mengelola sebuah perpustakaan desa. Selanjutnya kelemahan yang kedua adalah ruangan perpustakaan yang masih sangat sederhana tanpa mebeler, sehingga kegiatan membaca dilakukan sambil duduk lesehan. Kelemahan yang ketiga adalah dana yang 
diperuntukan untuk perpustakaan desa tersebut masih dalam kondisi yang minimal dan tidak pasti baik dalam segi jumlah maupun ketersediaannya. Kelemahan yang keempat, yang merupakan konsekuensi dari kelemahankelemahan sebelumnya adalah tingkat kunjungan pengguna perpustakaan yang relatif masih rendah.

Kondisi perpustakaan desa seperti tersebut di atas harus segera diperbaiki, apabila perpustakaan desa akan dijadikan basis dari kegiatan masyarakat di suatu desa. Oleh karena itu diperlukan upaya penguatan berbasis kebutuhan bagi perpustakaan-perpustakaan desa tersebut. Upaya penguatan perpustakaan desa sangat penting dilakukan karena sesuai dengan yang tercantum dalam SK Menteri Dalam Negeri Nomor 3 Tahun 2001 bahwa perpustakaan desa harus menjadi pusat pendidikan masyarakat dan merupakan bagian integral dari pembangunan desa (Keputusan Menteri Dalam Negeri Dan Otonomi Daerah Nomor 3 Tahun 2001 tentang Perpustakaan Desa/ Kelurahan, 2001).

Trimo (1992) menjelaskan bahwa berdasarkan hasil penelitian keberhasilan layanan perpustakaan ditentukan oleh faktor fasilitas seperti gedung, mebeler sebesar $5 \%$; oleh faktor koleksi sebesar $20 \%$; dan oleh faktor staf pengelola sebesar 75\%. Mengacu pada pernyataan tersebut, maka dapat dikatakan bahwa aspek utama dari sebuah perpustakaan adalah faktor fasilitas, koleksi, dan staf pengelola. Oleh karena itu, penguatan sebuah perpustakaan yang paling dasar dapat dimulai dengan memperbaiki dan menguatkan ketiga faktor tersebut. Demikian pula halnya dalam penguatan perpustakaan desa.

Berdasarkan hasil pengumpulan data di lapangan, maka penguatan perpustakaan desa di wilayah target kegiatan dapat dilakukan sebagai berikut:

\section{Penguatan Fasilitas Perpustakaan Desa}

Perpustakaan desa di desa-desa yang menjadi wilayah kegiatan masih diselenggarakan dengan fasilitas seadanya. Sebagai contoh, Perpustakaan Desa Margajaya menempati ruangan seluas $4 \mathrm{mx} 5 \mathrm{~m}$ yang terletak di samping kanan kantor desa. Di ruangan ditempatkan rak-rak berisi koleksi buku yang merapat ke tembok, dan di tengah ruangan digelar karpet yang bisa digunakan untuk duduk lesehan apabila pengunjung ingin membaca buku. Kondisi demikian tentu saja kurang nyaman untuk berkegiatan di perpustakaan, sehingga tidak cukup menarik masyarakat untuk datang mengunjungi perpustakaan desa tersebut. Oleh karena itu harus dilakukan pembenahan yang dimulai dengan disediakannya ruang perpustakaan desa yang memadai.

Trimo (1992) menjelaskan bahwa untuk sebuah perpustakaan yang sederhana paling sedikit memiliki empat ruangan, yaitu ruang untuk staf, ruang untuk menyimpan koleksi yang sekaligus bisa menjadi ruang baca pengguna perpustakaan, ruang gudang tempat menyimpan koleksi yang belum dikelola dan sekaligus ruang untuk pengelolaan koleksi. Tata letak ruanganruangan tersebut harus diatur sedemikian rupa sehingga memudahkan mobilitas pengguna di dalam perpustakaan. Ruangan perpustakaan tersebut harus ditata dengan rapi sehingga membuat nyaman baik pengguna perpustakaan maupun staf perpustakaan yang bersangkutan. Hal ini mencakup warna cat tembok yang membuat nyaman, pemilihan mebeler yang berkualitas baik dari segi estetika maupun pemanfaatannya, tata letak mebeler, sirkulasi udara di dalam ruangan, juga tersedianya fasilitas pendukung seperti toilet, mushola, kantin.

Di era informasi ini keberadaan komputer di suatu unit kerja merupakan suatu keniscayaan. Demikian pula halnya di perpustakaan desa idealnya dilengkapi dengan fasilitas komputer yang digunakan sebagai sarana pekerjaan administrasi perpustakaan, juga sebagai sarana akses internet untuk keperluan pengguna perpustakaan. Sebagai contoh, di Perpustakaan Desa Margajaya telah memiliki dua unit komputer yang digunakan untuk mengkases internet jika ada pengguna perpustakaan yang membutuhkan informasi, juga digunakan sebagai pelatihan komputer bagi mereka yang membutuhkan. Keberadaan komputer untuk akses internet dan pelatihan untuk meningkatkan keterampilan masyarakat akan merupakan nilai tambah bagi perpustakaan desa yang bersangkutan. Hal ini akan menjadi daya tarik bagi masyarakat untuk datang ke perpustakaan desa, mengingat di wilayah pedesaan masih banyak masyarakat yang belum memiliki sendiri komputer, dan belum terampil menggunakan komputer.

Pembelian komputer sebagai fasilitas perpustakaan desa mungkin akan sedikit memberatkan. Namun perpustakaan desa dalam hal ini melalui perangkat desa dapat mengajukan permohonan bantuan pada perusahaan/ industri yang berada di wilayah desa yang bersangkutan. Di wilayah Kecamatan Ngamprah banyak terdapat industri yang bisa diminta bantuan. Pada umumnya perusahaan memiliki dana CSR (Corporate Social Responsibility), sehingga mereka pada umumnya akan membantu dengan senang hati ketika ada proposal permintaan bantuan untuk perpustakaan. Sebagai contoh Perpustakaan Desa Margajaya mendapat bantuan tiga unit perangkat komputer dari Coca Cola Foundation.

\section{Penguatan Koleksi Perpustakaan Desa}

Penguatan koleksi merupakan aspek yang sangat penting, karena masyarakat sering mengidentikan institusi perpustakaan dengan koleksi buku-buku yang bisa dipinjam secara cuma-cuma. Apabila koleksi bukunya banyak, baru, dan mereka mendapatkan buku yang mereka butuhkan, maka perpustakaan tersebut akan dikatakan sebagai perpustakaan yang bagus. Oleh karena itu ketersediaan koleksi yang sesuai dengan selera masyarakat yang menjadi target layanan merupakan hal yang sangat penting. Hal ini akan merupakan daya tarik bagi masyarakat untuk datang memanfatkan perpustakaan. 
Menurut Evans \& Saponaro (2005) layanan dan koleksi suatu perpustakaan harus dikembangkan berdasarkan pada pemahaman tentang keinginan dan kebutuhan informasi masyarakat yang menjadi target layanan. Oleh karena itu pengelola perpustakaan harus melakukan survey kebutuhan informasi masyarakat yang akan menjadi target layanannya sebelum melakukan belanja buku atau sumber informasi lain yang akan menjadi koleksi perpustakaannya, sehingga nantinya koleksi yang disediakan relevan dengan kebutuhan informasi masyarakat penggunanya.

Perpustakaan desa juga dapat melakukan survey sederhana tentang kebutuhan informasi masyarakatnya dengan cara mengetahui karakteristik demografis masyarakat yang menjadi target layanannya. Misalnya dari segi usia, jenis kelamin, mata pencaharian, agama, dll. Mengacu pada karakteristik tersebut maka dapat disediakan koleksi buku untuk anak-anak, remaja, dewasa, buku yang berkaitan dengan wanita seperti memasak, keterampilan; buku tentang agama Islam apabila mayoritas penduduknya muslim, dst. Melalui pertimbangan tersebut diharapkan buku-buku koleksi perpustakaan dapat menarik minat masyarakat untuk datang ke perpustakaan.

Buku yang sesuai dengan selera akan memenuhi keinginan membaca bagi mereka yang sudah memiliki minat baca. Bagi yang belum suka membaca, mungkin akan membangkitkan keinginan untuk membaca ketika dia menemukan bahan bacaan yang menarik hatinya. Oleh karena itu buku-buku yang sesuai dengan kebutuhan akan mendorong meningkatkan minat berkujung ke perpustakaan dan diharapkan dapat meningkatkan literasi masyarakat.

Koleksi perpustakaan desa harus diolah sesuai dengan kaidah Ilmu Perpustakaan. Misalnya buku-buku diklasifikasikan sesuai dengan subjeknya, dibuat katalog sebagai alat bantu penelusuran, buku diberi label sesuai dengan nomor klasifikasinya, dan disimpan di rak secara berurut sesuai dengan nomor kalsifikasi tersebut, sehingga mudah ditemukan.

Pengadaan koleksi perpustakaan sering dihadapkan pada kendala dana untuk membeli koleksi tersebut. Ada alternatif lain yang bisa dilakukan ketika dana pembelian koleksi belum tersedia atau belum memadai. Seperti halnya dalam pembelian komputer, staf perpustakaan desa atau perangkat desa dapat mengajukan permintaan bantuan untuk pembelian buku-buku pada perusahaan/industri yang ada di wilayah desa yang bersangkutan. Apabila memungkinkan bantuan yang diminta berupa uang, sehingga staf perpustakaan dapat membeli buku sesuai dengan daftar buku yang akan dibeli yang sudah dibuat. Namun apabila perusahaan ingin memberi bantuan berupa barang, maka staf perpustakaan sebaiknya memberikan daftar buku yang akan dibeli, sehingga perusahaan dapat menyesuaikan.

Berkaitan dengan peran perpustakaan desa dalam diseminasi informasi kesehatan, maka koleksi perpustakaan desa harus dilengkapi dengan buku-buku atau sumber informasi lain tentang kesehatan. Jadi ketika staf perpustakaan desa akan melakukan pembelian koleksi perpustakaan, maka buku-buku tentang kesehatan harus menjadi perhatian. Staf perpustakaan dapat berkonsultasi dengan staf promotor kesehatan dari puskesmas mengenai buku-buku atau media lain yang sebaiknya diadakan di perpustakaan. Selanjutnya staf perpustakaan desa dapat meminta sumbangan buku dari Dinas Kesehatan Kabupaten Bandung Barat.

\section{Penguatan Staf Perpustakaan Desa}

Staf perpustakaan merupakan kunci keberhasilan layanan sebuah perpustakaan. Sebagaimana dinyatakan oleh Trimo (1992) bahwa keberhasilan perpustakaan 75\% ditentukan oleh kinerja staf perpustakaan. Oleh karena itu staf perpustakaan harus yang memiliki latar belakang pendidikan Ilmu Perpustakaan, sehingga perpustakaan akan dikelola secara profesional berdasarkan kaidahkaidah Ilmu Perpustakaan.

Selama ini perpustakaan desa di wilayah Kecamatan Ngamprah sebagian besar dikelola oleh ibu-ibu kader PKK. Ada pula perpustakaan desa yang dikelola oleh pengurus karang taruna. Kondisi ini mengakibatkan operasional perpustakaan desa sering terganggu karena ibu-ibu kader PKK sering harus melakukan kegiatan lain yang berkaitan dengan tanggungjawabnya sebagai kader PKK, sehingga perpustakaan desa sering harus tutup. Bisa dikatakan bahwa mengelola perpustakaan hanya dilakukan pada waktu senggang saja.

Pengelola perpustakaan desa yang sekarang ada, yaitu ibu-ibu kader PKK sudah pernah mendapat pelatihan pengelolaan perpustakaan dari Dinas Perpustakaan dan Arsip Kabupaten Bandung Barat, sehingga koleksi yang sekarang ada di perpustakaan desa sudah dikelola sesuai dengan kaidah pengelolaan koleksi perpustakaan, meskipun masih dalam kondisi yang sederhana.

Untuk meningkatkan kinerja perpustakaan desa, maka idealnya perpustakaan desa memiliki staf yang bertugas khusus mengelola perpustakaan, sehingga dia akan fokus bekerja mengelola dan mengembangkan perpustakaan. Selanjutnya staf perpustakaan desa harus memiliki latar belakang pendidikan Ilmu Perpustakaan, sehingga dia akan mengelola perpustakaan desa secara profesional sesuai dengan kaidah-kaidah Ilmu Perpustakaan. Disamping itu staf pengelola perpustakaan desa juga sebaiknya orangnya ramah, memiliki jiwa menolong, dan memiliki semangat untuk mengajak masyarakat memanfaatkan perpustakaan desa. Dengan demikian perpustakaan desa akan tampil lebih meyakinkan sehingga akan menarik masyarakat untuk berkunjung dan memanfaatkan semua fasilitas yang disediakan.

Staf perpustakaan desa juga dapat berperan aktif dalam diseminasi informasi kesehatan melalui memperkenalkan buku-buku atau media seperti poster, alat perga kesehatan yang merupakan koleksi perpustakaan. 
Staf perpustakaan desa dapat menjawab pertanyaan pengunjung perpustakaan seputar masalah kesehatan dengan memberikan buku atau sumber informasi lain yang relevan. Apabila di perpustakaan desa sudah tersedia fasilitas komputer untuk akses internet, maka staf perpustakaan dapat membantu pemustaka untuk mengakses internet dan menemukan informasi yang dibutuhkan. Bahkan staf perpustakaan dapat mencatat pertanyaan-pertanyaan tentang masalah kesehatan yang belum terjawab karena perpustakaan belum memiliki sumber informasi tersebut. Selanjutnya staf perpustakaan dapat berkonsultasi tentang masalah tersebut dengan staf promotor kesehatan dari puskesmas atau dengan bidan desa, sehingga kebutuhan informasi seseorang yang bertanya tersebut dapat terpenuhi.

\section{Penguatan Kebijakan Pendukung Perpustakaan Desa}

Selain penguatan pada aspek utama yang telah dijelaskan di atas, perpustakaan desa juga harus dikuatkan oleh adanya kebijakan-kebijakan pemerintah desa yang mendukung, yaitu kebijakan tentang alokasi anggaran, kebijakan tentang rekrutmen staf perpustakaan desa, dan kebijakan tentang promosi atau memasyarakatkan perpustakaan desa.

Kebijakan yang pertama dan penting adalah yang berkaitan dengan alokasi anggaran untuk dana operasional perpustakaan desa. Diharapkan dari dana desa yang diberikan oleh pemerintah pusat, sebagian disisihkan untuk dana operasional perpustakaan desa. Hal ini bisa tercapai apabila pemerintah desa terutama kepala desa memiliki perhatian dan kesadaran akan pentingnya peran perpustakaan bagi masyarakat.

Selanjutnya perpustakaan desa juga bisa mengajukan permintaan bantuan dana dari industri/perusahaan yang berada di wilayah desa yang bersangkutan. Komariah, Saepudin, \& Rodiah, (2018) menjelaskan bahwa perusahaan memiliki dana CSR yang pada umumnya dialokasikan untuk pengembangan pendidikan masyarakat dan perpustakaan merupakan sarana pendidikan non formal, sehingga sangat tepat apabila dana CSR diberikan pada perpustakaan.

Disamping kebijakan yang berkaitan dengan masalah dana, kebijakan pemerintah desa juga sangat penting pada aspek staf perpustakaan. Idealnya perpustakaan desa harus memiliki staf yang bertugas khusus mengelola perpustakaan, sehingga perpustakaan dapat dikelola dan dikembangkan dengan optimal. Dalam hal ini pemerintah desa bisa melakukan penerimaan pegawai baru sebagai staf desa yang bertugas mengelola perpustakaan desa. Sudah bukan saatnya lagi pengelolaan perpustakaan desa merupakan beban kerja tambahan bagi ibu-ibu kader PKK atau pengurus Karang Taruna atau staf desa.

Selanjutnya kebijakan yang juga sangat penting adalah bagaimana pemerintah desa berupaya memas- yarakatkan perpustakaan desa tersebut. Beberapa alternatif kebijakan yang bisa diambil antara lain, pertama memerintahkan aparat desa yang paling dekat kepada masyarakat yaitu para Ketua RT untuk menginformasikan keberadaan perpustakaan desa pada masyarakat. Kegiatan sosialisasi ini juga bisa dibantu oleh ibu-ibu Kader PKK yang sering mengadakan pertemuan dengan ibuibu di wilayah binaannya. Agar kegiatan sosialisasi perpustakaan ini lebih efektif, maka sebaiknya diberikan pembekalan pengetahuan tentang perpustakaan desa yang bersangkutan kepada para Ketua RT dan para Kader PKK. Saepudin (2017) menjelaskan bahwa sosialisasi taman bacaan masyarakat dapat dilakukan dengan mengundang anak-anak pada saat acara pembukaan taman bacaan. Hal ini dapat dilakukan pula dalam sosialisasi perpustakaan desa, karena di perpustakaan desa terdapat koleksi buku bacaan untuk anak-anak. Mengundang anak-anak yang didampingi orangtuanya ke perpustakaan desa dapat memperkenalkan anak pada bahan bacaan sekaligus menumbuhkan minat baca sejak dini.

Kegiatan sosialisasi perpustakaan desa tersebut harus didukung oleh kesiapan perpustakaannya untuk dikunjungi oleh masyarakat. Kesiapan tersebut meliputi siap secara fisik seperti tersedia ruangan yang memadai dan nyaman untuk kegiatan membaca buku atau mengakses internet, tersedia koleksi yang menarik yang sesuai dengan kebutuhan masyarakat, juga tersedia staf yang ramah dan siap membantu apabila pengunjung mengalami kesulitan.

\section{SIMPULAN}

Penguatan perpustakaan desa merupakan suatu keniscayaan. Hal ini sangat penting karena perpustakaan desa harus menjadi pusat informasi masyarakat yang berada di wilayah suatu desa, dimana masyarakat dapat mencari informasi yang mereka butuhkan dengan mudah dan cepat serta tidak dipungut biaya.

Perpustakaan desa yang sudah memiliki fasilitas bagus yang dilengkapi dengan adanya komputer untuk akses internet, yang koleksinya lengkap dan relevan dengan kebutuhan informasi masyarakat, yang dikelola oleh staf perpustakaan yang profesional, serta didukung oleh kebijakan pemerintah desa yang proporsional, maka akan menjadi pusat kegiatan belajar mandiri dan belajar seumur hidup bagi semua lapisan masyarakat. Penguatan perpustakaan desa juga dapat meningkatkan peran perpustakaan desa dalam diseminasi informasi kesehatan pada masyarakat. Sumber-sumber informasi tentang kesehatan dapat menjadi koleksi perpustakaan desa yang bisa diakses dengan mudah oleh masyarakat. Disamping itu staf perpustakaan dapat membantu masyarakat untuk mendapatkan informasi tentang kesehatan yang mereka butuhkan. 


\section{UCAPAN TERIMAKASIH}

Kegiatan Pengabdian Pada Masyarakat (PPM) ini dari mulai persiapan, pelaksanaan di lapangan, sampai dengan penyusunan laporan tidak terlepas dari dukungan dan budi baik baik dari berbagai pihak. Oleh karena itu, dengan kerendahan hati, perkenankanlah kami menyampaikan rasa terima kasih yang sebesar-besarnya kepada Direktur Riset, Pengabdian Pada Masyarakat dan Inovasi Universitas Padjadjaran, Dekan dan Wakil Dekan serta Manajer Riset dan Kerjasama Fakultas Ilmu Komunikasi Universitas Padjadjaran yang telah memberikan kesempatan kepada kami untuk melaksanakan kegiatan PPM ini, Kepala Desa beserta aparat Desa Margajaya Kecamatan Ngamprah Kabupaten Bandung Barat, Para Pengelola Perpustakaan Desa dan Perpustakaan sekolah di wilayah kerja Puskesmas Cimareme, dan semua pelaksana kegiatan hingga pelaksanaan PPM ini berjalan dengan dengan baik.

\section{DAFTAR PUSTAKA}

Evans, G. E., \& Saponaro, M. Z. (2005). Developing Library and Information Center Collections (5th ed.). Westport: Greenwood Piblishing.

Keputusan Menteri Dalam Negeri Dan Otonomi Daerah Nomor 3 Tahun 2001 tentang Perpustakaan Desa/ Kelurahan (2001). Indonesia.
Komariah, N., Saepudin, E., \& Rodiah, S. (2018). CSR For Library A Study On Csr Of Bank Bjb For Building The Gasibu Library In Bandung, West Java. In International Conference on Media and Communication Studies (ICOMACS 2018) (pp. 261-264). New York: Atlantis Press. Retrieved from http://toc.proceedings.com/41146webtoc.pdf

NS, S. (2006). Perpustakaan dan Masyarakat. Jakarta: Sagung Seto.

Rodiah, S., Lusiana, E., \& Agustine, M. (2016). Pemberdayaan Kader PKK dalam Usaha Penyebarluasan Informasi Kesehatan di Kecamatan Jatinangor Kabupaten Sumedang. Dharmakarya: 6, (1), 5-8.

Trimo, S. (1992). Pedoman pelaksanaan perpustakaan. Bandung: Remadja Rosdakarya.

Undang-Undang Nomor 46 Tahun 2014 tentang Sistem Informasi Kesehatan (2014). Indonesia.

Undang-Undang Republik Indonesia Nomor 36 Tahun 2009 Tentang Kesehatan, Pub. L. No. 36, http:// sireka.pom.go.id (2009). Indonesia. Retrieved from http://sireka.pom.go.id/requirement/UU-362009-Kesehatan.pdf

Undang-Undang Republik Indonesia Nomor 43 Tahun 2007 tentang Perpustakaan (2007). Indonesia. 